constants of 7-14 and $0.4-1 \mathrm{~ms},\left(V_{\mathrm{m}}=-90\right.$ to $\left.-70 \mathrm{mV}\right)$, respectively, and the estimated values for the single channel conductance were $2-3 \mathrm{pS}$.

As shown in Fig. 3, the absence of NMDA channels was confirmed in isolated patches exposed to NMDA ( $30 \mu \mathrm{M}$, four patches) or asparate $(30-100 \mu \mathrm{M}$, two patches); the same patches invariably gave currents with glutamate, quisqualate or kainate (Fig. $3 b$ ). Furthermore, the possibility that trypsin treatment of cells ${ }^{5}$ caused a selective loss of NMDA receptors ${ }^{22}$ was excluded by experiments such as that depicted in Fig. $4 a$, showing that type- 2 astrocytes in mechanically dissociated explant cultures $^{19}$ were also insensitive to NMDA. Figure 4 illustrates a direct comparison of the channels activated in granule neurons and in type- 2 astrocytes, present in the same explant cultures. In the granule cells, NMDA and glutamate produced currents that opened predominantly to levels above $30 \mathrm{pS}$. Although $\mathrm{Mg}^{2+}$ blocks the NMDA-activated 45-pS conductance in neurons ${ }^{13}$, in cerebellar type- 2 astrocytes $\mathrm{Mg}^{2+}(0.5 \mathrm{mM})$ did not induce a flickery block of any of the multiple levels (including the 45-pS levels) activated by quisqualate (eight patches).

Our results demonstrate that type- 2 astrocytes have both quisqualate- and kainate-activated channels. In certain respects these are clearly similar to neuronal glutamate channels ${ }^{11,12}$ but the data also suggest some differences. For example, certain neurons lacking NMDA receptors fail to give 45-pS openings in response to quisqualate ${ }^{23}$. By contrast, in the astrocytes, $45-\mathrm{pS}$ events were readily obtained with quisqualate, despite the absence of NMDA receptors. Moreover, the fact that $\mathrm{Mg}^{2+}$ blocks NMDA $45-\mathrm{pS}$ events in neurons ${ }^{13}$ but not the quisqualate $45-\mathrm{pS}$ levels in astrocytes, raises the intriguing possibility that some quisqualate 45-pS openings may be $\mathrm{Mg}$-insensitive in neurons (see also Fig. 4 legend). Kainate currents in type-2 astrocytes differed from those described in some neurons ${ }^{11,12}$, in the lack of openings above $30 \mathrm{pS}$. This may reflect differences in the kainate channels present in the two cell types, or it may indicate that in neurons kainate events above $30 \mathrm{pS}$ are produced by the activation of $\mathrm{NMDA}^{11}$ or quisqualate receptors. As well as possessing amino-acid receptors, type- 2 astrocytes show some other 'neuronal' characteristics both in their antigenic proper$\operatorname{ties}^{24,25}$ and in their voltage-activated channels ${ }^{26}$. Our results further suggest that a proportion of glutamate receptors, or messenger (m) RNA encoding these receptors, derived from whole brain tissue may originate from glia. This could be one reason why mRA injected into Xenopus oocytes induces a low density of NMDA receptors ${ }^{27,28}$, compared with quisqualate and kainate receptors.

What is the functional significance of the astrocytic glutamate receptors? The type- 2 astrocytes possess end-feet, in close apposition to the nodes of Ranvier in vivo ${ }^{9,10}$, that are well positioned to be activated by any axonal release of transmitter. Such release of glutamate from axons has previously been reported ${ }^{29,30}$. Our finding that the receptors remain active in the continued presence of glutamate suggests that any axonally released transmitter acting on nodal astrocytes would cause a steady change in the local ionic environment, and in electrical excitability of the axon. In addition, the ability of type- 2 astrocytes to 'detect' or respond to glutamate may be important in the formation or maintenance of the node; such responses may also play a role in the interactions between axons and migrating progenitors of the type- 2 astrocytes, which also seem to possess glutamate receptors 5 .

\footnotetext{
Received 20 March; accepted 24 April 1989

1. Watkins, J. C. \& Olverman, H. J. Trends Neurosci. 10, 265-272 (1987)

2. Mayer, M. L. \& Westbrook, G. L. Prog. Neurobiol. 28, 197-276 (1987).

3. Bowman, C. L. \& Kimelberg, H. K. Nature 311, 656-659 (1984)

4. Kettenman. H., Backus, K. H. \& Schachner. M. Neurosci. Lett. 52, 25-29 (1984)

5. Gallo, V., Giovannini, C., Suergiu, R. \& Levi, G. J. Neurochem. 52, 1-9 (1989)

6. Sontheimer, H., Kettenman, H., Backus, K. H. \& Schachner, M. Glia 1, 328-336 (1988).

7. Hamill, O. P., Marty, A., Neher, E., Sakmann, B. \& Sigworth, F. J. Pfügers Arch. ges. Physiol. 391, 85-100 (1981).
}

8. Wilkin, G. P. \& Levi, G. in Astrocytes, Vol. 1. 245-268 (Academic. London, 1986). 9. French-Constant, C. \& Raff, M. C. Nature 323, 335-338 (1986).

10. Miller, R., Fulton, Barbara P. \& Raff, M. C. Eur. J. Neurosci. 1, 171-180 (1989).

11. Cull-Candy, S. G. \& Usowicz, M. M. Nature 325, 525-528 (1987)

12. Jahr. C. E. \& Stevens, C. F. Nature 325, 522-525 (1987).

13. Nowak, L., Bregestovski, P., Ascher, P.. Herbet. A. \& Prochiantz, A. Nature 307, 462-465 (1984).

14. Ishida, A. T. \& Neyton, J. Proc. natn. Acad. Sci. U.S.A. 82, 1837-1841 (1985)

15. Cull-Candy, S. G. \& Usowicz, M. M. Brain Res, 402, 182-187 (1987).

16. Ascher, P. \& Nowak, L. J. Physiol. Lond. 399, 207-226 (1988).

17. Cull-Candy, S. G. \& Usowicz, M. M. J. Physiol. Lond. (in the press).

18. Brew, H. \& Attwell, D. Nature 327, 707-709 (1987).

19. Cull-Candy, S. G., Howe, J. R. \& Ogden, D. C. J. Physiol. Lond. 400, 189-222 (1988).

20. Johnson, J. W. \& Ascher. P. Nature 325, 529-531 (1987)

21. Mayer, M. L., Westbrook, G. L. \& Vyklicky. L., Jr J. Neurophysiol. 60, 645-663 (1988)

22. Akaike. N., Kaneda, M., Hori, N. \& Krishtal. O. A. Neurosci. Lett. 87, 75-79 (1988)

23. Llano, I., Marty, A., Johnson, J. W., Ascher, P. \& Gahwiler, B. Proc. natn. Acad. Sci. U.S.A. 85, 3221-3225 (1988)

24. Raff, M. C.. Milier, R. H. \& Noble, M. Nature 303, 390-397 (1983).

25. Levi, G., Gailo, V. \& Ciotti, M. T. Proc. natn. Acad. Sci. US.A. 83, 1504-1508 (1986)

26. Barres, B. A., Chun, L. L. Y. \& Corey, D. P. Glia 1, 10-30 (1988).

27. Gundersen, C. B., Miledi, R. \& Parker, I. Proc. R. Soc. B221, 127-143 (1984)

28. Verdoorn. T. A., Kleckner, N. W. \& Dingledine, R. Science 238, 1114-1116 (1988)

29. Weinreich, D. \& Hammerslag, R. Brain Res. 84, 137-142 (1975).

30. Abbott, N. J., Hassan, S. \& Lieberman, E. M. J. Physiol, Lond. 398, 63P (1988).

ACKNOWLEDGEMENTS. We thank Corinne Symonds for help with cell culture and antibody labeling, Alistair Mathie, David Colquhoun, Barbara Fulton and Martin Raff for helpful comments and discussions. This work was supported by the Wellcome Trust, the MRC and EMBO (V.G.)

\section{Interleukin-2 production used to detect antigenic peptide recognition by T-helper lymphocytes from asymptomatic HIV-seropositive individuals}

\author{
Mario Clerici*, Naomi I. Stocks*, Robert A. Zajac $†$, \\ R. Neal Boswell $\dagger$, Denise C. Bernstein*, \\ Dean L. Mann $\div$, Gene M. Shearer* \\ \& Jay A. Berzofsky $\S$
}

* Experimental Immunology Branch, $\doteqdot$ Viral Carcinogenesis Branch and $\S$ Metabolism Branch, National Cancer Institute, National Institutes of Health, Bethesda Maryland 20892, USA

† HIV Unit/SGHMMM, Wilford Hall, Lackland AFB, Texas 28236, USA

T LYMPHOCYTES from mice ${ }^{1}$ and healthy humans ${ }^{2}$ immunized against the human immunodeficiency virus (HIV) envelope have recently been shown to recognize two antigenic regions of the gp160 HIV-envelope protein which have been located on the basis of amphipathicity ${ }^{3-6}$. In HIV-infected humans, T-cell proliferative responses are lost soon after infection ${ }^{7.8}$. Here we demonstrate that interleukin-2 production is often retained even when proliferative activity is absent, and that it can be used to monitor $T$-helper cell responses by HIV-seropositive donors. We use this approach to investigate the T-helper cell response of 42 asymptomatic HIVseropositive patients to four synthetic gp160 peptides and to influenza $A$ virus, an antigen requiring intact CD4 T-helper cell function. As many as $67 \%$ of the HIV-seropositive donors who retain responsiveness to influenza $A$ virus respond to a single peptide, and $85-90 \%$ responded to at least one of the peptides.

We tested the ability of peripheral blood leukocytes (PBL) from asymptomatic, HIV seropositive $\left(\mathrm{HIV}^{+}\right)$, Walter Reed Stage 1 and 2 patients (all of whom had $>400 \mathrm{CD}^{+}$cells $\mathrm{mm}^{-3}$ ) (ref. 9) to produce interleukin-2 (IL-2) when stimulated in vitro with influenza-A virus (FLU), or with four HIV envelope peptides: T1, T2, TH4.1, and P18 (Fig. 1; Table 1). The PBL from an $\mathrm{HIV}^{-}$donor (Fig. 1a) generated a strong IL-2 response to FLU, but failed to respond to any of the HIV synthetic peptides. PBL from a Walter Reed Stage 1 patient $\left(1,463 \mathrm{CD}^{+}\right.$ cells $\mathrm{mm}^{-3}$ ) (Fig. $1 b$ ) responded as well to FLU as those from the $\mathrm{HIV}^{-}$control, and also generated strong IL-2 responses to $\mathrm{T} 1$ and TH4.1, with lower but positive responses to T2 and P18. 
TABLE 1 T-helper cell responses of PBL from HIV seropositive and seronegative donors to influenza A virus and four HIV synthetic peptides

\begin{tabular}{|c|c|c|c|c|c|c|c|c|c|c|c|c|c|c|c|c|c|c|c|c|c|}
\hline \multirow{2}{*}{$\begin{array}{l}\text { Donor } \\
\text { number }\end{array}$} & \multicolumn{5}{|c|}{ IL-2 production response } & \multicolumn{5}{|c|}{ Proliferation response } & \multirow{2}{*}{$\begin{array}{l}\text { Donor } \\
\text { number }\end{array}$} & \multicolumn{5}{|c|}{ IL-2 production response } & \multicolumn{5}{|c|}{ Proliferation response } \\
\hline & FLU & T1 & T2 & TH4.1 & P18 & FLU & T1 & T2 & TH4.1 & P18 & & FLU & T1 & $\mathrm{T} 2$ & TH4.1 & P18 & FLU & $\mathrm{T} 1$ & $\mathrm{~T} 2$ & TH4.1 & P18 \\
\hline $363^{*}$ & 6.7 & $\underline{9.5}$ & 2.8 & $\underline{2.3}$ & 3.1 & 2.7 & 1.6 & 2.9 & 0.3 & 0.4 & $516 \dagger$ & 1.8 & 1.5 & 1.4 & 1.2 & 1.9 & 1.4 & 0.6 & 1.4 & 0.1 & 0.1 \\
\hline 471 & 2.6 & 2.2 & $\underline{2.8}$ & 1.6 & 3.7 & 0.4 & 0.2 & 0.8 & 0.2 & 0.2 & 575 & 0.9 & 0.8 & 0.5 & 0.9 & 0.8 & 0.9 & 1.7 & $\underline{2.2}$ & 0.1 & 0.1 \\
\hline 136 & 2.3 & 2.5 & $\overline{0.6}$ & 0.3 & $\overline{1.1}$ & 1.1 & 0.8 & 0.4 & 0.4 & 0.8 & 176 & 1.3 & 1.4 & 1.1 & 1.3 & 2.0 & 2.9 & 1.2 & $\overline{0.2}$ & 0.5 & 0.2 \\
\hline 300 & 2.1 & 0.8 & 0.8 & 1.2 & 1.0 & 1.0 & 0.3 & 0.3 & 0.2 & 0.3 & 415 & 1.9 & 1.4 & 0.9 & 0.7 & 1.0 & 1.2 & 1.3 & 0.6 & 0.8 & 1.0 \\
\hline 346 & 2.1 & 1.9 & 1.8 & 2.2 & 2.1 & 3.5 & $\underline{5.2}$ & 2.4 & 2.2 & 2.3 & 756 & 1.0 & 0.8 & 0.8 & 0.8 & 0.9 & 0.7 & 1.3 & 1.2 & 0.2 & 0.3 \\
\hline 429 & 6.4 & 2.1 & $\underline{2.1}$ & 1.6 & 1.0 & 6.4 & $\underline{2.5}$ & 1.2 & 0.8 & $\overline{1.1}$ & 328 & 1.8 & 1.0 & 1.6 & & & 0.9 & 1.4 & 1.0 & & \\
\hline 149 & 6.2 & 9.6 & 1.1 & & & 1.5 & $\overline{1.5}$ & 1.1 & & & 20 & 1.2 & 1.6 & 0.6 & & & 0.8 & 1.2 & 1.2 & & \\
\hline 146 & 4.7 & 2.7 & 3.0 & & & 0.9 & 0.5 & 0.6 & & & 769 & 1.6 & 0.6 & 1.0 & 0.9 & 1.0 & & & & & \\
\hline 318 & 12.0 & 0.9 & 1.0 & & & 0.9 & 0.8 & 0.7 & & & 352 & 1.0 & 0.4 & 0.5 & 0.8 & 0.9 & & & & & \\
\hline 320 & 5.5 & 1.1 & 0.8 & & & 1.7 & 0.4 & 0.5 & & & 373 & 1.7 & 0.8 & 0.3 & 1.0 & 0.9 & & & & & \\
\hline 326 & 3.7 & $\underline{3.2}$ & 0.8 & & & 3.5 & 0.7 & 1.4 & & & & & & & & & & & & & \\
\hline 382 & 19.1 & 20.0 & 24.1 & & & 0.9 & 0.8 & 0.9 & & & $43 \ddagger$ & 9.8 & 0.4 & 0.3 & 0.8 & 0.3 & 23.7 & 0.5 & 0.3 & 0.2 & 0.2 \\
\hline 331 & 6.2 & 1.4 & 2.2 & & & 1.1 & 0.7 & 0.8 & & & 44 & 12.1 & 0.8 & 0.9 & 0.1 & 0.2 & 6.8 & 0.5 & 0.6 & 0.7 & 0.7 \\
\hline 108 & 2.3 & $\underline{2.1}$ & $\overline{1.5}$ & & & 0.6 & $\underline{2.0}$ & $\underline{2.3}$ & & & 45 & 10.9 & 1.3 & 1.2 & 0.9 & 0.8 & 8.7 & 0.9 & 1.3 & 0.6 & 1.0 \\
\hline 186 & 2.2 & 1.7 & 2.7 & & & 0.8 & $\overline{1.1}$ & $\overline{0.8}$ & & & 46 & 5.7 & 1.0 & 0.9 & 1.1 & 1.0 & 4.1 & 0.8 & 0.4 & 0.4 & 0.8 \\
\hline 250 & 4.9 & 5.5 & 2.8 & & & 2.4 & 1.9 & 1.5 & & & 47 & 5.7 & 0.7 & 0.8 & 1.0 & 1.1 & 55.9 & 0.5 & 0.5 & 0.4 & 0.2 \\
\hline 425 & 3.1 & $\underline{2.0}$ & 2.3 & & & 1.1 & $\underline{2.2}$ & 1.8 & & & 48 & 4.6 & 1.6 & 0.3 & 0.3 & 0.2 & 42.3 & 0.8 & 0.6 & 0.2 & 0.1 \\
\hline 253 & 96.8 & 2.1 & 2.7 & $\underline{4.5}$ & 7.8 & & & & & & 49 & 3.4 & 1.1 & 1.1 & 0.7 & 0.6 & 3.7 & 0.1 & 0.2 & 0.3 & 0.2 \\
\hline 772 & 2.8 & $\underline{2.5}$ & $\overline{2.1}$ & 2.9 & $\overline{1.6}$ & & & & & & 50 & 3.1 & 1.1 & 0.2 & 0.5 & 0.7 & 15.2 & 1.1 & 0.9 & 0.8 & 1.0 \\
\hline 399 & 2.9 & 1.4 & 3.4 & 2.8 & 2.4 & & & & & & 51 & 2.9 & 0.4 & 0.5 & 1.0 & 0.8 & 19.9 & 0.7 & 0.6 & 0.8 & 0.2 \\
\hline \multirow[t]{2}{*}{ LW } & 4.5 & 2.8 & $0 . \overline{7}$ & $\overline{2.2}$ & $\overline{1.2}$ & & & & & & 52 & 4.3 & 0.4 & 0.3 & 0.2 & 0.2 & 7.7 & 0.8 & 0.5 & 0.9 & 0.5 \\
\hline & & & & & & & & & & & 53 & 4.4 & 0.8 & 1.1 & 0.2 & 0.3 & 17.1 & 1.1 & 1.0 & 0.4 & 0.3 \\
\hline $513 \div$ & 1.1 & 0.7 & 0.9 & 1.1 & 1.2 & 1.1 & 0.3 & 0.8 & 0.1 & 0.1 & 54 & 7.8 & 0.1 & 0.1 & 1.1 & 0.3 & 5.9 & 0.1 & 0.1 & 0.1 & 0.2 \\
\hline 308 & 0.9 & 0.6 & 0.7 & 1.1 & 0.6 & 1.3 & 0.5 & 0.5 & 0.4 & 0.8 & 55 & 7.9 & 0.3 & 0.2 & 0.6 & 0.2 & 5.9 & 0.1 & 0.1 & 0.1 & 0.2 \\
\hline 353 & 1.8 & 0.9 & 1.1 & 0.8 & 1.1 & 1.2 & 1.2 & 1.1 & 1.3 & 0.4 & 56 & 6.4 & 1.0 & 1.2 & 0.8 & 0.6 & 6.8 & 0.6 & 0.7 & 0.8 & 0.6 \\
\hline 757 & 1.1 & 1.4 & 1.4 & 1.7 & 1.2 & 1.4 & 0.4 & 0.6 & 1.7 & 1.8 & 57 & 5.8 & 1.0 & 0.7 & 1.3 & 0.4 & 7.3 & 0.4 & 0.3 & 0.3 & 0.2 \\
\hline 1 & 1.9 & 0.9 & 1.1 & 1.0 & 0.6 & 0.6 & 0.9 & 1.4 & 0.5 & 1.1 & 58 & 10.5 & 1.0 & 1.2 & 0.3 & 0.3 & 7.6 & 0.4 & 0.4 & & \\
\hline 304 & 1.4 & 1.0 & 0.8 & 1.2 & 0.9 & 0.7 & 1.5 & 1.0 & 0.4 & 1.1 & 59 & 5.6 & 1.2 & 1.0 & 1.1 & 0.4 & 17.5 & 1.2 & 1.3 & & \\
\hline 671 & 1.6 & 1.0 & 1.2 & 2.0 & 1.7 & 1.3 & 0.9 & 1.3 & 0.7 & 1.3 & 60 & 12.6 & 0.3 & 0.6 & 0.1 & 0.4 & 21.4 & 2.3 & 2.1 & & \\
\hline 417 & 1.6 & 1.5 & 1.0 & $\overline{1.0}$ & 0.7 & 1.1 & 1.0 & 1.2 & 1.0 & 1.4 & 61 & 11.7 & 0.7 & 1.2 & 1.1 & & 15.7 & 1.1 & 0.9 & & \\
\hline 267 & 1.7 & 1.6 & 0.9 & 0.6 & 0.5 & 1.2 & 1.1 & 1.3 & 0.4 & 0.3 & 62 & 5.3 & 0.4 & 0.6 & 1.0 & 1.1 & & & & & \\
\hline 79 & 1.6 & 0.8 & 0.8 & 0.8 & 1.4 & 1.1 & 0.8 & 1.5 & 0.1 & 0.1 & 63 & 3.3 & 0.7 & 0.4 & 0.7 & 0.7 & & & & & \\
\hline 327 & 1.9 & 1.3 & 1.2 & 1.7 & 1.6 & 2.5 & 1.5 & 1.4 & 0.1 & 0.1 & & & & & & & & & & & \\
\hline
\end{tabular}

Values indicate stimulation indices (see Fig 1). Underlined values indicate stimulation indices $\geqslant 2.0$ for responses to the T1, T2, TH4.1 and P18 peptides. Peptides were tested

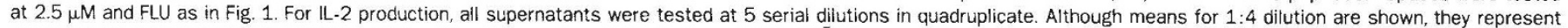
results of 20 assays wells. Proliferation assays (day 7$)$ were done in triplicate wells $\left(3 \times 10^{5}\right.$ PBL per well).

* The first 21 donors were $\mathrm{HIV}^{+}$individuals whose PBL generated IL-2 in response to FLU. The donor designated LW is a laboratory worker who was accidently infected with HIV-1 $1_{\text {IIIB }}$

$\uparrow$ The second 21 donors were $\mathrm{HIV}^{+}$individuals whose PBL did not generate IL-2 in responses to FLU.

\$ Donors 43-63 were $\mathrm{HIV}^{-}$individuals whose PBL were used as controls.

PBL from the other Walter Reed Stage 1 patient $\left(583 \mathrm{CD}^{+}\right.$ cells $\mathrm{mm}^{-3}$ ) (Fig. 1c) failed to respond either to FLU or to any of the four peptides. Thus, we have identified two types of $\mathrm{HIV}^{+}$ individuals, one who responds to FLU and to the four HIV synthetic peptides, and another who does not respond to FLU or to any of the four peptides tested. Using the experimental design shown in Fig. 1, we tested PBL from an additional $40 \mathrm{HIV}^{+}$individuals and $20 \mathrm{HIV}^{-}$control donors (Table 1). We also tested all donors for response to tetanus toxoid and found a complete concordance with their responsiveness to FLU.

Of the $21 \mathrm{HIV}^{+}$donors who responded to FLU by IL-2 production, only 5 of the 17 tested responded with T-cell proliferation against FLU. In contrast, all of the 19 normal controls responded by $\mathrm{T}$-cell proliferation against FLU. This result indicates that capacity for T-cell proliferation is lost earlier in HIV infection than for IL-2 production. This observation may in part account for earlier failures to detect responses to HIV antigen $\mathrm{s}^{10}$. To be sure that the failure to observe proliferation despite a positive IL-2 response was not simply due to a difference in the kinetics of the T-cell proliferative response between the $\mathrm{HIV}^{+}$ individuals and the controls, we investigated the kinetics in three $\mathrm{HIV}^{+}$individuals and one control. The control was positive for IL-2 production on day 7 , for proliferation on days 5,7 , and 9 and weakly responsive on day 11 of culture. By contrast, the three $\mathrm{HIV}^{+}$donors were all negative for proliferative response on days $5,7,9$, and 11 , despite being reproducibly positive for IL-2 production in the same experiment (data not shown). Also, five donors who were unresponsive to FLU by both assays remained negative at all four time points. Therefore, the difference is a qualitative defect in proliferative response and not just a difference in kinetics. Follow up studies of these donors may indicate whether the difference observed at this early time point after infection is of prognostic significance.

Among the 21 HIV donors who responded to FLU, 14 responded to $\mathrm{T} 1$ and 12 responded to T2. PBL from 6 of 10 of these same donors tested with the TH4.1 peptide responded, and 5 of 10 tested with peptide P18 responded. Only two of the $21 \mathrm{HIV}^{+}$donors who were unresponsive to FLU responded to any of the four peptides. None of the $21 \mathrm{HIV}^{-} / \mathrm{FLU}^{+}$control donors responded to any of the peptides. Two of the $\mathrm{HIV}^{+}$ donors who responded to FLU and to one or more of the HIV

TABLE 2 Lack of correlation between HLA class II antigen expression in $\mathrm{HIV}^{+} / \mathrm{FLU}^{+}$donors and $\mathrm{LL}-2$ response to HIV synthetic peptides

\begin{tabular}{cccccccc} 
& \multicolumn{3}{c}{ HLA antigens } & & \multicolumn{3}{c}{ L-2 response to peptide } \\
\cline { 2 - 3 } \cline { 6 - 7 } Donor & DR & DQ & T1 & T2 & TH4.1 & P18 \\
& & & & & & & \\
363 & 13,52 & 1 & + & + & + & + \\
471 & $2,8,52$ & 1 & + & + & - & + \\
149 & $4,52,53$ & 3 & + & - & NT & NT \\
146 & 3,7 & 2,3 & + & + & NT & NT \\
318 & 3,52 & 1 & - & - & NT & NT \\
320 & $3,4,52$ & $?$ & - & - & NT & NT \\
326 & 1,8 & 1 & + & - & NT & NT \\
382 & $2,3,52$ & $?$ & + & + & NT & NT \\
331 & $11,13,52$ & 1,3 & - & + & NT & NT \\
108 & $1,9,52,53$ & 1,3 & + & - & NT & NT \\
425 & $1,4,52,53$ & 1 & + & + & NT & NT \\
772 & $8,13,52$ & 1 & + & + & + & - \\
LW & $1,2,52$ & 1 & + & - & + & - \\
\hline
\end{tabular}

NT, not tested. 
peptides by IL-2 production were available for re-testing one to three months later, and were found to be reproducibly positive against the same antigens. One $\mathrm{HIV}^{+}$donor who showed no response to FLU or to any of the peptides remained negative to all of the antigens when retested one year later. PBL from 13 of the $21 \mathrm{HIV}^{+}$donors who responded to FLU were typed for HLA. In this small sample, no correlation was noted between the expression of a particular HLA class I or class II antigen and ability to respond to any of the synthetic peptides (Table 2).

The individuals who responded to the synthetic peptides were two-to-three times as frequent among $\mathrm{HIV}^{+} / \mathrm{FLU}^{+}$donors as among all $\mathrm{HIV}^{+}$donors (Table 3 ). All donors, irrespective of their HIV status, were responsive to HLA alloantigens, which is indicative of their ability to respond to some antigenic stimulus by IL-2 production. It has recently been demonstrated that T-helper cell responses by human PBL to FLU require $\mathrm{MHC}$ self-restricted $\mathrm{CD}^{+}$T-helper cells whereas the response to alloantigens can use either the $\mathrm{CD}^{+}$or $\mathrm{CD} 8^{+}$pathway of T-helper cell activity ${ }^{7}$ (C.S. Via, G. Tsokos and G.M.S., manuscript in preparation). Also, $40-50 \%$ of asymptomatic $\mathrm{HIV}^{+}$ individuals and AIDS patients have a selective defect in CD4mediated but not in CD8-mediated T-helper cell function (M. C. et al., submitted). Therefore, almost all individuals responsive to one or more of the HIV synthetic peptides also responded to FLU, probably because this group of 21 of the $42 \mathrm{HIV}^{+}$ donors tested retained intact T-helper cell function to a CD4dependent antigen. In contrast, 20 of the 21 patients unresponsive to FLU may also have failed to respond to the peptides because they had lost responsiveness to any CD4-dependent antigens. Thus, it is important when testing any $\mathrm{HIV}^{+}$individuals

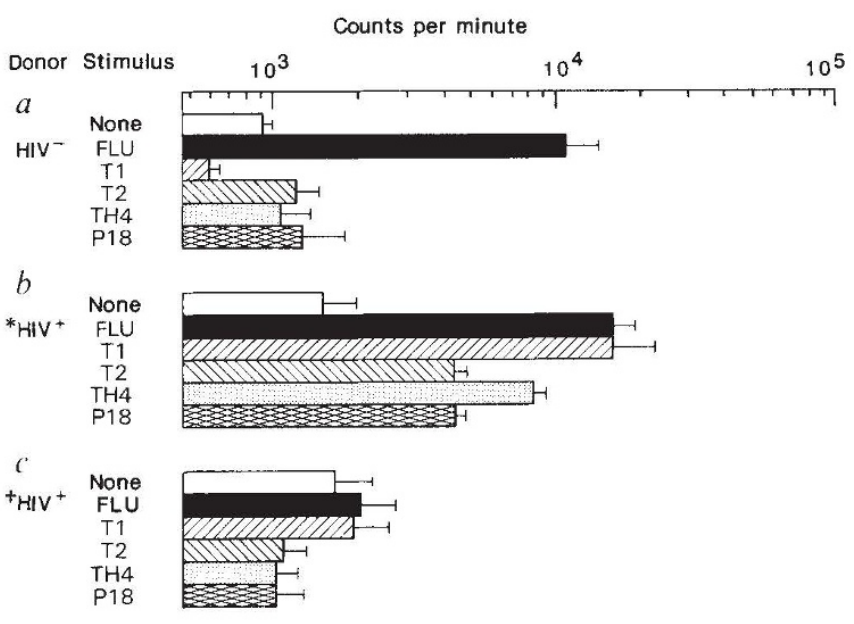

FIG. 1 IL-2 production by PBL. from an HIV seronegative (a) and two HIV seropositive Walter Reed Stage 1 patients ( $b$ and $c$ ).

METHOD. PBL were unstimulated, or stimulated with influenza $A$ virus ( $A /$ Hong Kong RX73, H3N2, grown in chicken eggs, final culture dilution 1:1,000) or with the HIV synthetic peptides T1, T2, TH4 or P18 at $2.5 \mu \mathrm{M}$. EnvT1 and T2 correspond to amino-acid residues $428-443$ and $112-124$ of gp120 (IIIB isolate) respectively ${ }^{1}$. Peptide TH4.1 corresponds to residues $834-848$ of gp160 (P. Hale et al., submitted). P18, corresponding to residues 315-329 of gp160 (IIIB), is a major epitope for murine anti-HIV cytolytic effector cells $^{11}$. PBL $\left(3 \times 10^{6}\right)$ were cultured in $2 \mathrm{ml} \mathrm{RPMI-1640}$ medium supplemented with $5 \%$ pooled $\mathrm{AB}^{+}$human serum for $7 \mathrm{~d}$ in the presence of anti-TAC (IL-2 receptor p55 chain) monocional antibody (to prevent IL-2 consumption). Supernatants of these cultures were collected, and five twofold dilutions of the supernatants were added to cultures of the IL-2dependent CTLL cell line. Twenty-four hours later, the stimulated CTLL cultures were pulsed with $\left[{ }^{3} \mathrm{H}\right]$ thymidine; thymidine incorporation was determined $18 \mathrm{~h}$ later, and is expressed in counts per minute. The data points shown in Fig. 1 and Table 1 are for a culture supernatant dilution of 1:4. We have used a stimulation index (ratio of counts per minute in stimulated cultures to that in unstimulated cultures) of greater than 2.0 as an indication of positive response. For key, see Table 1.
TABLE 3 Positive T-helper cell responses to the four HIV synthetic peptides as a function of ability to respond to influenza A virus

\begin{tabular}{|c|c|c|c|c|c|c|c|c|}
\hline \multirow{2}{*}{$\begin{array}{l}\text { Donor } \\
\text { category }\end{array}$} & \multicolumn{4}{|c|}{ IL-2 production } & \multicolumn{4}{|c|}{ Proliferation } \\
\hline & $T 1$ & $\mathrm{~T} 2$ & TH4.1 & P18 & $\mathrm{T} 1$ & T2 & TH4.1 & P18 \\
\hline All $\mathrm{HIV}^{+}$ & $\begin{array}{l}14 / 42 \\
(33 \%)\end{array}$ & $\begin{array}{l}12 / 42 \\
(29 \%)\end{array}$ & $\begin{array}{c}6 / 29 \\
(21 \%)\end{array}$ & $\begin{array}{l}6 / 29 \\
(21 \%)\end{array}$ & $\begin{array}{l}4 / 35 \\
(11 \%)\end{array}$ & $\begin{array}{l}4 / 35 \\
(11 \%)\end{array}$ & $\begin{array}{l}1 / 22 \\
(5 \%)\end{array}$ & $\begin{array}{l}1 / 22 \\
(5 \%)\end{array}$ \\
\hline $\mathrm{HIV}^{+}, \mathrm{FLU}^{+}$ & $\begin{array}{l}14 / 21 \\
(67 \%)\end{array}$ & $\begin{array}{l}12 / 21 \\
(57 \%)\end{array}$ & $\begin{array}{c}6 / 10 \\
(60 \%)\end{array}$ & $\begin{array}{l}5 / 10 \\
(50 \%)\end{array}$ & $\begin{array}{c}4 / 17 \\
(24 \%)\end{array}$ & $\begin{array}{c}3 / 17 \\
(18 \%)\end{array}$ & $\begin{array}{c}1 / 6 \\
(17 \%)\end{array}$ & $\begin{array}{c}1 / 6 \\
(17 \%)\end{array}$ \\
\hline
\end{tabular}

Fractions and per cent (in parentheses) given for each donor category. All of the HIV seronegative control donors responded to FLU, but none of them responded to any of the four HIV synthetic peptides.

for T-helper cell responses to HIV antigens to establish whether these patients have retained an intact CD4 T-helper cell pathway.

Of the 21 FLU-responsive $\mathrm{HIV}^{+}$donors, 18 responded to at least one of the four T-cell epitopes. Of the 10 donors we were able to test with all four peptides, nine responded to at least one peptide. Therefore, these four helper T-cell epitopes are sufficient to elicit responses in $85-90 \%$ of an HLA-diverse group of patients. For the purposes of vaccine development, it has been feared that many $\mathrm{T}$-cell epitopes would be necessary to cover most or all of the outbred human population with extensive HLA polymorphism. But the present results are much encouraging: only a few selected epitopes may be sufficient.
Received 18 November 1988; accepted 19 April 1989

1. Cease, K. B. et al. Proc. natn. Acad. Sci. U.S.A. 84, 4249-4253 (1987)

2. Berzofsky, J. A. et al. Nature 334, 706-708 (1988).

3. Detisi, C. \& Berzofsky, J. A. Proc. natn, Acad. Sci. U.S.A. 82, 7048-7052 (1985).

4. Spouge, J. L. et al. J. Immun. 138, 204-212 (1987).

5. Margalit, H. et al. J. Immun 138, 2213-2229 (1987).

6. Berzofsicy, $\mathrm{A}$. et at Immunol Rev $98,0-52(1987)$.

6. Berzoss.

8. Lane, H. C. et al. New Engl. J. Med. 313, $79-84$ (1985).

9. Redfield, R. R. New Engl. J. Med. 314, 131-132 (1986)

10. Wahren, B. et al. J. Virol. 61, 2017-2023 (1987).

11. Takahashi, H. et al. Proc. natn. Acad. Sci. U.S.A. 85, 3105-3109 (1988).

ACKNOWLEDGEMENTS. We thank Drs Steven M. Banks and David Alling (NIAID, NIH) for statistical analysis of the data for possible HLA associations, and Ms Judy Kress for preparing the manuscript. The opinions expressed herein are the private views of the authors and are not to be construed as official or as reflecting the views of the Department of the Air Force or the Department of Defense.

\section{An engineered poliovirus chimaera elicits broadly reactive HIV-1 neutralizing antibodies}

\author{
David J. Evans*, Jane McKeating†, Janet M. Meredith*, \\ Karen L. Burke*, Kersi Katrak $\ddagger$, Ann John‡, \\ Morag Ferguson $\ddagger$, Philip D. Minorł, Robin A. Weiss $\uparrow$ \\ $\&$ Jeffrey W. Almond*
}

* Department of Microbiology, University of Reading, London Road, Reading RG1 5AQ, UK

$\dagger$ Institute of Cancer Research, Chester Beatty Laboratories, Fulham Road, London SW3 6JB, UK

$\ddagger$ National Institute for Biological Standards and Control, Blanche Lane, South Mimms, Potters Bar, Hertfordshire EN6 3QR. UK

THE Sabin type 1 vaccine strain of poliovirus is probably the safest and most successful live-attenuated vaccine virus used in humans. Its widespread use since the early $1960 \mathrm{~s}$ has contributed significantly to the virtual eradication of poliomyelitis in developed countries. We have reported previously the construction of an intertypic antigen chimaera of poliovirus, based on the Sabin 1 strain, and proposed that this virus could be modified to express on its surface antigenic determinants from other pathogens ${ }^{1}$. We describe here the construction and characterization of a poliovirus 